\title{
EVALUASI KEKUATAN LENTUR REL UIC54 MENGGUNAKAN METODE BEAM ON ELASTIC FOUNDATION (BOEF)
}

\author{
Ayu Prativi ${ }^{1}$, ayu.prativi@ppi.ac.id \\ Wahyu Tamtomo Adi², tamtomo@ppi.ac.id \\ ${ }^{1,2}$ Teknologi Bangunan dan Jalur Perkeretaapian, Politeknik Perkeretaapian Indonesia
}

\begin{abstract}
ABSTRAK
Di Indonesia, dimensi profil baja rel telah ditentukan dalam Peraturan Menteri Perhubungan No. 60 tahun 2012. Salah satu jenis rel yang umum digunakan untuk jalan rel dengan lebar 1067mm adalah rel tipe UIC54. Namun, penentuan tipe profil rel di Indonesia belum dilengkapi dengan analisis kekuatan struktur profil rel dalam menahan beban yang bekerja di atasnya. Sehingga, jurnal ini akan membahas perhitungan analisis kekuatan struktur rel UIC54 dalam menahan beban lokomotif CC 203, CC 205, dan CC 206. Metode perhitungan menggunakan metode Beam on Elastic Foundation (BOEF) yang mengasumsikan perilaku rel sebagai balok kontinu yang menerima beban di atas tumpuan pondasi elastis. Nilai kekuatan rel UIC dituliskan dalam bentuk angka faktor keamanan (SF). Hasil perhitungan menunjukkan bahwa nilai SF terkritis rel dalam menerima beban lokomotif CC 203, CC 205, dan CC 206 berturut-turut adalah sebesar 10,94; 8,93; dan 9,67. Berdasarkan hasil perhitungan BoEF, rel UIC54 memiliki nilai kemanan yang tinggi dalam menahan beban dinamis lokomotif.
\end{abstract}

Kata Kunci: Rel UIC54, Beam On Elastic Foundation (BOEF), beban dinamis lokomotif

\section{ABSTRACT}

In Indonesia, the dimensions of the rail steel profile have been determined by Minister of Transportation Regulation Number 60 of 2012. The commonly rail which used for $1067 \mathrm{~mm}$ railway width is the rail type UIC54. However, the determination of rail profile type in Indonesia has not been equipped with an analysis of the rail profile strength to support the load acting on it. Thus, this journal will discuss the calculation of the UIC54 rail strength analysis to support locomotive loads of CC 203, CC 205, and CC 206. The calculation is using Beam on Elastic Foundation (BOEF) method which assumes rail behavior as a continuous beam that support loads above an elastic foundation. The value of UIC rail strength is written in the form of safety factors $(S F)$. The calculation results show that the value of the most critical rail SF to support locomotive loads CC 203, CC 205, and CC 206 are 10.94; 8.93; and 9.67. Based on the results of BoEF calculations, the UIC54 rail has a high safety factor to support the dynamic load of the locomotive.

Keywords: UIC54 Rail, Beam On Elastic Foundation (BOEF), locomotive dynamic load.

\section{PENDAHULUAN}

Di Indonesia, spesifikasi teknis jalan rel telah diatur dalam Peraturan Menteri Perhubungan No. 60 tahun 2012. Dalam peraturan tersebut, jarak antar bantalan, profil rel, material bantalan, dan dimensi bantalan telah ditentukan berdasarkan kelas jalan rel dan lebar jalan rel. Penentuan dimensi komponen rel tersebut digunakan untuk kepraktisan penggunaan di lapangan. Namun, di dalam PM tersebut belum dicantumkan dasar analisis teknis yang digunakan untuk penentuan dimensi masing-masing komponen jalan rel. Sehingga diperlukan pengembangan analisis perhitungan teknis sangat diperlukan untuk menguji faktor kekuatan rel baik dari segi keamanan maupun keekonomisannya sebagai fungsi dari ilmu rekayasa jalan rel (railway engineering). Dengan demikian, diharapkan suatu struktur memiliki tingkat keamanan yang baik dalam menahan beban yang diterimanya serta memiliki ukuran yang cukup ekonomis untuk dapat menghasilkan kemampuan menahan beban yang diterimanya. 


\section{TINJAUAN PUSTAKA}

\subsection{Beban dinamis roda kereta}

Perencanaan beban roda vertikal secara empiris akibat faktor pengaruh dinamis dapat ditulis menjadi persamaan (1).

$\mathrm{P}=\phi \times \mathrm{Ps}$

di mana $\mathrm{P}$ adalah beban roda rencana, Ps adalah beban roda statis; dan $\phi$ adalah angka faktor pengaruh dinamis.

Faktor pengaruh dinamis dapat ditentukan dengan menggunakan berbagai formula seperti AREA, Eisenmann, ORE, British Railways, Germany, dll. Salah satu jenis formula perhitungan faktor pengaruh dinamis, yaitu menggunakan rumus Germany pada persamaan (2) dan (3). Jika V merupakan kecepatan kereta api $(\mathrm{km} / \mathrm{jam})$, maka: Faktor pengaruh dinamis untuk $\mathrm{V} \leq 100 \mathrm{~km} / \mathrm{jam}$, $\phi=1+\frac{V^{2}}{30000}$

Faktor pengaruh dinamis untuk $\mathrm{V}>100 \mathrm{~km} / \mathrm{jam}$,

$\phi=1+\frac{4,5 V^{2}}{10^{5}}-\frac{1,5 V^{3}}{10^{7}}$

\subsection{Analisis Beam on Elastic Foundation (BOEF)}

Analisis Beam on Elastic Foundation (BOEF) atau dapat disebut juga sebagai balok pada pondasi elastis merupakan sebuah pemodelan yang digunakan untuk merencanakan struktur jalan rel. Analisis ini digunakan untuk menghitung tegangan lentur pada dasar rel akibat beban roda kereta api rencana. Pemodelan ini dikembangkan pertama kali oleh Winkler (1867) ketika menganalisis rel sebagai balok menerus di atas tumpuan pondasi elastis linier.

Posisi kesetimbangan pada balok elastis yang menerima beban sebesar $\mathrm{q}(\mathrm{x})$ ditampilkan pada Gambar 1. Pada gambar tersebut, distribusi beban $\mathrm{q}(\mathrm{x})$ menyebabkan balok mengalami deformasi sehingga berpindah secara vertikal sebesar $y(x)$ di bawah sumbu balok tak berdeformasi. Akibat dari deformai vertikal balok, terjadi tegangan kontak permukaan sebesar $\mathrm{p}(\mathrm{x})$.

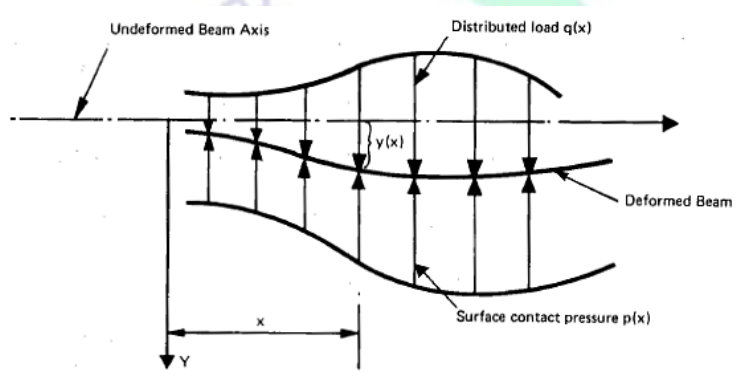

Gambar 1. Kondisi keseimbangan pada balok berdeformasi yang menerima beban $\mathrm{q}(\mathrm{x})$.

Persamaan diferensial untuk teori lentur pada balok elastis seperti pada Gambar 1 ditulis dalam persamaan (4).

$\mathrm{EI} \frac{d^{4} y}{d x^{4}}+\mathrm{p}(\mathrm{x})=\mathrm{q}(\mathrm{x})$

di mana $y(x)$ adalah defleksi vertikal pada jarak $x$, $\mathrm{q}(\mathrm{x})$ adalah distribusi beban vertikal, EI adalah kekakuan lentur rel, dan $\mathrm{p}(\mathrm{x})$ adalah tegangan kontak menerus antara bantalan dan balas.

Winkler kemudian memodifikasi persamaan menjadi persamaan (5) berikut:

$\mathrm{EI} \frac{d^{4} y}{d x^{4}}+\mathrm{ky}(\mathrm{x})=\mathrm{q}(\mathrm{x})$

di mana $y(x)$ adalah defleksi vertikal pada jarak $\mathrm{x}, \mathrm{q}(\mathrm{x})$ adalah distribusi beban vertikal, EI adalah kekakuan lentur rel, $\mathrm{k}$ adalah modulus pondasi.

Persamaan (5) merepresentasikan respon balok menerus yang dipasang di atas pegas dan menerima beban sebesar $\mathrm{q}(\mathrm{x})$ seperti pada Gambar 2.2. Kenyataannya, beban roda kereta api yang menyentuh rel merupakan beban terpusat, sehingga beban $\mathrm{q}(\mathrm{x})$ pada persamaan (2.5) harus diubah menjadi bentuk beban roda terpusat P. Solusi defleksi, gaya geser, dan momen lentur pada rel akibat beban roda $\mathrm{P}$ kemudian ditentukan pada persamaan (6), persamaan (7), dan persamaan (8).

$\mathrm{y}_{\mathrm{x}}=\frac{\mathrm{P} \beta \mathrm{e}^{-\beta \mathrm{x}}}{2 \mathrm{k}}(\cos \beta \mathrm{x}+\sin \beta \mathrm{x})$

$\mathrm{V}_{\mathrm{x}}=\frac{\mathrm{Pe}^{-\beta \mathrm{x}}}{2} \cos \beta \mathrm{x}$

$\mathrm{M}_{\mathrm{x}}=\frac{\mathrm{P} \beta \mathrm{e}^{-\beta \mathrm{x}}}{4}(\cos \beta \mathrm{x}-\sin \beta \mathrm{x})$

di mana $\mathrm{y}_{\mathrm{x}}$ adalah defleksi rel, $\mathrm{V}_{\mathrm{x}}$ adalah gaya geser rel, $\mathrm{M}_{\mathrm{x}}$ adalah momen lentur pada dasar rel, $\mathrm{x}$ adalah jarak terhadap titik acuan, $\mathrm{P}$ adalah beban roda terpusat, dan $\beta$ adalah faktor kekakuan lentur balok yang berperilaku sebagai tumpuan elastis. Variabel $\beta$ dihitung dengan menggunaan persamaan (9)

$\beta=\sqrt{\frac{k}{4 E I}}$

di mana $\mathrm{k}$ adalah modulus jalan rel (Mpa), E adalah modulus Young baja rel (Mpa), I adalah momen inersia rel $\left(\mathrm{mm}^{4}\right)$. 


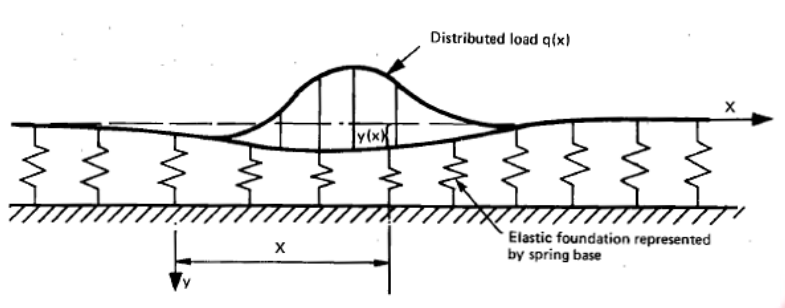

Gambar 2. Ilustrasi kondisi beban $\mathrm{q}(\mathrm{x})$ yang membebani balok tak hingga di atas tumpuan menerus dengan dasar pondasi elastis.

\subsection{Kekakuan jalan rel (k)}

Kekakuan jalan rel atau yang juga disebut modulus jalan rel (k) merupakan parameter yang menghubungkan perilaku elastis jalan rel dalam menerima beban yang bekerja terhadapnya. Modulus jalan rel (k) diartikan sebagai gaya/unit dari defleksi/unit panjang rel. Pada rel tunggal nilai modulus jalan rel ditentukan menggunakan persamaan (10).

$\mathrm{k}=\frac{\mathrm{P}_{\mathrm{S}}}{\mathrm{Y} . \mathrm{S} .10^{3}}$

dimana Ps adalah beban roda statis pada setiap rel $(\mathrm{kN}), \mathrm{Y}$ adalah defleksi total yang diukur pada tumpuan rel $(\mathrm{mm})$, dan $\mathrm{S}$ adalah jarak antar bantalan $(\mathrm{mm})$. AREA merekomendasikan nilai modulus jalan rel sebesar 13,8 Mpa (2000psi) untuk menentukan defleksi rel pada struktur jalan rel yang direncanakan dengan rel ringan hingga sedang. Selain menggunakan rekomendasi dari AREA, nilai modulus jalan rel juga dapat ditentukan berdasarkan kondisi jalan relnya (AHLF, 1975) menggunakan Tabel 1.

Tabel 1. Modulus jalan rel (k) berdasarkan kondisi jalan rel (AHLF, 1975)

\begin{tabular}{|c|c|c|c|c|}
\hline $\begin{array}{c}\text { Kondisi } \\
\text { bantalan }\end{array}$ & $\begin{array}{c}\text { Tebal } \\
\text { balas } \\
(\mathbf{m m})\end{array}$ & $\begin{array}{c}\text { Kondisi } \\
\text { balas }\end{array}$ & $\begin{array}{c}\text { Kondisi } \\
\text { subgrade }\end{array}$ & $\begin{array}{c}\mathbf{k} \\
(\mathbf{M P a})\end{array}$ \\
\hline Jelek & 150 & $\begin{array}{c}\text { Material } \\
\text { relatif } \\
\text { tidak } \\
\text { bersuara, } \\
\text { berlumpur }\end{array}$ & $\begin{array}{c}\text { Drainasi } \\
\text { buruk, } \\
\text { lunak }\end{array}$ & 6,9 \\
\hline $\begin{array}{c}\text { Cukup } \\
\text { baik }\end{array}$ & 150 & $\begin{array}{c}\text { Cukup } \\
\text { bersuara, } \\
\text { layak } \\
\text { bebas } \\
\text { lumpur }\end{array}$ & $\begin{array}{c}\text { Sedang, } \\
\text { cukup } \\
\text { terdrainasi }\end{array}$ & 13,8 \\
\hline Baik & 150 & $\begin{array}{c}\text { Bersuara, } \\
\text { batu } \\
\text { pecah, } \\
\text { bebas } \\
\text { lumpur }\end{array}$ & $\begin{array}{c}\text { Sedang, } \\
\text { cukup } \\
\text { terdrainasi }\end{array}$ & 20,7 \\
\hline
\end{tabular}

\begin{tabular}{|c|c|c|c|c|}
\hline Baik & 300 & $\begin{array}{c}\text { Bersuara, } \\
\text { batu } \\
\text { pecah, } \\
\text { bebas } \\
\text { lumpur }\end{array}$ & $\begin{array}{c}\text { Sedang, } \\
\text { cukup } \\
\text { terdrainasi }\end{array}$ & 27,6 \\
\hline Baik & 450 & $\begin{array}{c}\text { Bersih, } \\
\text { bersuara, } \\
\text { batu } \\
\text { pecah }\end{array}$ & $\begin{array}{c}\text { Baik, } \\
\text { padat, } \\
\text { drainasi } \\
\text { baik }\end{array}$ & 34,5 \\
\hline
\end{tabular}

\subsection{Tegangan ijin rel}

AREA (1973) menyarankan nilai tegangan ijin untuk rel menerus dengan pengelasan ditentukan pada bagian dasar rel. (Robnett, dkk., 1975). Penentuan nilai tegnagan ijin rel berdasarkan implikasinya untuk menghindari terjadinya retak akibat kelelahan material. Tegangan ijin rel harus berada di bawah nilai tegangan leleh material. Dengan kata lain, nilai tegangan ijin rel masih berada dalam fase elastis material baja. Pendekatan umum untuk menghitung tegangan lentur ijin (oall)yang diusulkan oleh Hay (1953) diberikan pada persamaan (11).

$\sigma_{\text {all }}=\frac{\sigma_{\mathrm{y}}-\sigma_{\mathrm{t}}}{(1+\mathrm{A})(1+\mathrm{B})(1+\mathrm{C})(1+\mathrm{D})}$

dimana $\sigma_{\text {all }}$ adalah tegangan ijin rel, $\sigma_{\mathrm{y}}$ adalah tegangan leleh baja rel (MPa), $\sigma_{t}$ adalah tegangan akibat perubahan suhu, A adalah faktor reduksi akibat beban lentur lateral, B adalah faktor reduksi akibat kondisi jalan rel, $\mathrm{C}$ adalah faktor reduksi akibat keausan dan korosi rel, dan D adalah faktor reduksi akibat ketidakseimbangan superelevasi. Masing-masing faktor reduksi dapat ditentukan menggunakan Tabel 2.

Tabel 2. Faktor Reduksi Tegangan Ijin Rel Akibat Pengaruh Kondisi Lapangan

\begin{tabular}{|l|c|c|c|}
\hline $\begin{array}{c}\text { Faktor Reduksi } \\
\text { Tegangan (MPa) }\end{array}$ & Hay & Clarke & Magee \\
\hline $\begin{array}{l}\text { akibat lentur lateral, } \\
\text { A }\end{array}$ & $\begin{array}{c}15 \\
\%\end{array}$ & $15 \%$ & $20 \%$ \\
\hline $\begin{array}{l}\text { akibat kondisi jalan } \\
\text { rel, B }\end{array}$ & $\begin{array}{c}25 \\
\%\end{array}$ & $25 \%$ & $\begin{array}{c}25 \% \text { untuk } \\
\text { jalan rel } \\
\text { bercabang } \\
35 \% \text { untuk } \\
\text { sambungan } \\
\text { jalan rel }\end{array}$ \\
\hline $\begin{array}{l}\text { akibat keausan dan } \\
\text { korosi rel, C }\end{array}$ & 10 & $10 \%$ & $15 \%$ \\
\hline $\begin{array}{l}\text { akibat } \\
\text { ketidakseimbangan } \\
\text { superelevasi, D }\end{array}$ & $5 \%$ & $5 \%$ & - \\
\hline
\end{tabular}




\section{METODOLOGI PENELITIAN}

Alur pengerjaan penelitian dilakukan seperti pada diagram alir Gambar 3. Pada tahap studi pustaka dilakukan pengumpulan referensi yang berkaitan dengan kriteria perencanaan struktur rel terutama yang berkaitan dengan metode Beam on Elastic Foundation (BoEF). Tahap studi pustaka juga merupakan langkah dalam menentukan parameterparameter yang harus diketahui agar dapat menghitung kekuatan rel dengan metode BoEF. Setelah parameter tersebut ditentukan, maka dilakukan kembali studi literatur untuk mengumpulkan data parameter yang diperlukan.

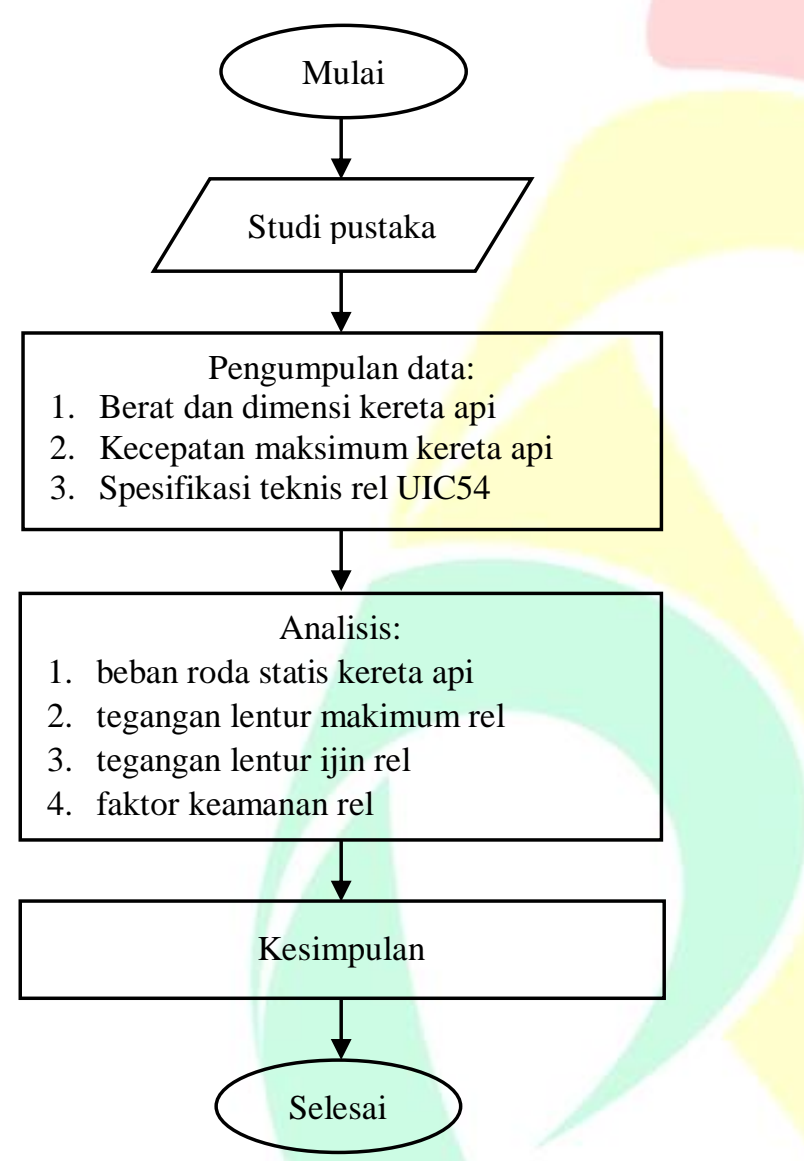

Gambar 3. Diagram alir penelitian

Data yang telah terkumpul diolah dan dianalisis dengan tahapan sebagai berikut:

a. Tentukan faktor pengaruh dinamis roda kereta menggunakan persamaan (2) atau berdasarkan kecepatan rencana kereta.

. Tentukan beban dinamis roda kereta menggunakan persamaan (1).

c. Tentukan momen lentur yang terjadi pada dasar rel menggunakan persamaan (8) berdasarkan parameter standar rel UIC54 dan menggunakan Tabel 1 untuk menentukan nilai modulus jalan rel (k). d. Tentukan tegangan lentur rel akibat beban roda dengan cara membagi hasil perhitungan momen lentur pada langkah $\mathrm{c}$ dengan nilai statis momen dasar rel.

e. Tentukan tegangan lentur ijin rel menggunakan persamaan (11).

f. Tentukan nilai angka faktor keamanan (SF) rel dengan cara membagi tegangan lentur ijin (langkah e) dengan tegangan lentur akibat beban roda (langkah d). Rel dinyatakan aman jika nilai $\mathrm{SF}>1$, kritis jika $\mathrm{SF}=1$, dan tidak aman jika $\mathrm{SF}<1$.

\section{HASIL DAN PEMBAHASAN}

\subsection{Parameter jalan rel}

Parameter teknis jalan rel yang digunakan dalam analisis Beam on Elastic Foundation (BEOF), meliputi: tegangan leleh, modulus elastisitas, momen inersia, statis momen, modulus jalan rel, dan tegangan ijin baja rel. Perhitungan tegangan leleh baja rel UIC54 yang digunakan pada Persamaan (10) ditentukan menggunakan parameter tegangan ultimit baja rel minimal yang disyaratkan, yaitu sebesar $1080 \mathrm{MPa}$. Dengan demikian analisis tegangan ijin baja rel pada penelitian ini ditentukan dalam kondisi batas ultimit. Selain tegangan leleh, analisis tegangan lentur ijin $\left(\sigma_{i j i n}\right)$ pada penelitian ini mengasumsikan beberapa hal berikut: a. tegangan akibat perubahan suhu cuaca diabaikan; b. reduksi tegangan ijin rel akibat pengaruh kondisi lapangan menggunakan nilai yang diusulkan oleh Hay dan Clarke dalam Tabel 1, yaitu A $=15 \%, \mathrm{~B}=25 \%, \mathrm{C}$ $=10 \%$, dan $\mathrm{D}=5 \%$. Data parameter teknis jalan rel disajikan dalam Tabel 2.

Tabel 2. Parameter Teknis Jalan Rel

\begin{tabular}{|c|c|c|}
\hline Parameter rel & Nilai & Satuan \\
\hline Tegangan tarik, $\sigma_{\mathrm{t}}$ & 1080 & $\mathrm{MPa}$ \\
\hline Modulus elastisitas, $\mathrm{E}$ & 200000 & $\mathrm{MPa}$ \\
\hline Momen inersia $\mathrm{X}, \mathrm{I}_{\mathrm{x}}$ & 23460000 & $\mathrm{~mm}^{4}$ \\
\hline Statis momen $\mathrm{X}, \mathrm{Z}_{\mathrm{x}}$ & 312900 & $\mathrm{~mm}^{3}$ \\
\hline Tegangan ijin rel, $\sigma_{\mathrm{ijin}}$ & 650,48 & $\mathrm{MPa}$ \\
\hline Modulus jalan rel, $\mathrm{k}$ & 27,60 & $\mathrm{~N} / \mathrm{mm}^{2}$ \\
\hline
\end{tabular}

\subsection{Beban roda dinamis lokomotif}

Spesifikasi kecepatan maksimum sarana, diameter roda lokomotif, dan berat siap lokomotif disajikan dalam Tabel 3. Kecepatan rencana yang digunakan dalam peneltian ini sesuai dengan PM no. 60/2012, yaitu sebesar $1,25 \times$ kecepatan maksimum. 
Kemudian beban roda dinamis lokomotif ditentukan dengan menggunakan Persamaan (1), (2), dan (3). Hasil perhitungan beban roda dinamis disajikan dalam Tabel 4. Nilai faktor pengaruh dinamis $(\phi)$ kereta pada kecepatan rencana untuk CC 203, CC 205, dan CC 206 adalah 1,521, 1,333 dan 1,750. Nilai beban roda dinamis ini akan digunakan dalam perhitungan momen lentur pembahasan berikutnya.

Tabel 3. Spesifikasi Lokomotif CC 203, CC 205, dan CC 206

\begin{tabular}{|c|c|c|c|c|}
\hline $\begin{array}{c}\text { Tipe } \\
\text { lokomot } \\
\text { if }\end{array}$ & $\begin{array}{c}\mathrm{V}_{\text {maks }} \\
(\mathrm{km} / \mathrm{ja} \\
\mathrm{m})\end{array}$ & $\begin{array}{c}\mathrm{V}_{\text {renc }} \\
(\mathrm{km} / \mathrm{ja} \\
\mathrm{m})\end{array}$ & $\begin{array}{c}\text { Diamet } \\
\text { er roda, } \\
\mathrm{D}(\mathrm{mm})\end{array}$ & $\begin{array}{c}\mathrm{W}_{\text {siap }} \\
\text { lokomot } \\
\text { if }(\mathrm{N})\end{array}$ \\
\hline $\mathrm{CC} 203$ & 100 & 125 & 914 & 840000 \\
\hline $\mathrm{CC} 205$ & 80 & 100 & 1067 & $\begin{array}{c}106400 \\
0\end{array}$ \\
\hline $\mathrm{CC} 206$ & 120 & 150 & 914 & 882000 \\
\hline
\end{tabular}

Tabel 4. Beban Dinamis Lokomotif CC 203, CC 205, dan CC 206

\begin{tabular}{|c|c|c|c|}
\hline $\begin{array}{c}\text { Tipe } \\
\text { lokomotif }\end{array}$ & $\begin{array}{c}\text { Berat } \\
\text { siap } \\
\text { lokomotif } \\
(\mathrm{N})\end{array}$ & $\begin{array}{c}\text { Faktor } \\
\text { pengaruh } \\
\text { dinamis, } \phi\end{array}$ & $\begin{array}{c}\text { Beban roda } \\
\text { dinamis, } \mathrm{P}_{\mathrm{d}} \\
(\mathrm{N})\end{array}$ \\
\hline CC 203 & 840000 & 1,410 & 98710,94 \\
\hline CC 205 & 1064000 & 1,333 & 118222,22 \\
\hline CC 206 & 882000 & 1,506 & 110709,38 \\
\hline
\end{tabular}

\subsection{Faktor keamanan rel}

Hasil perhitungan momen lentur rel menggunakan persamaan (8) ditampilkan dalam Gambar 5, Gambar 6 dan Gambar 7. Pada setiap gambar tersebut, kondisi pembebanan jalan rel aktual menyebabkan rel mengalami kombinasi beban pada beberapa titik sebagai akibat interaksi roda yang berdekatan. Nilai momen terbesar terpusat pada rel yang terletak tepat di bawah roda kereta.
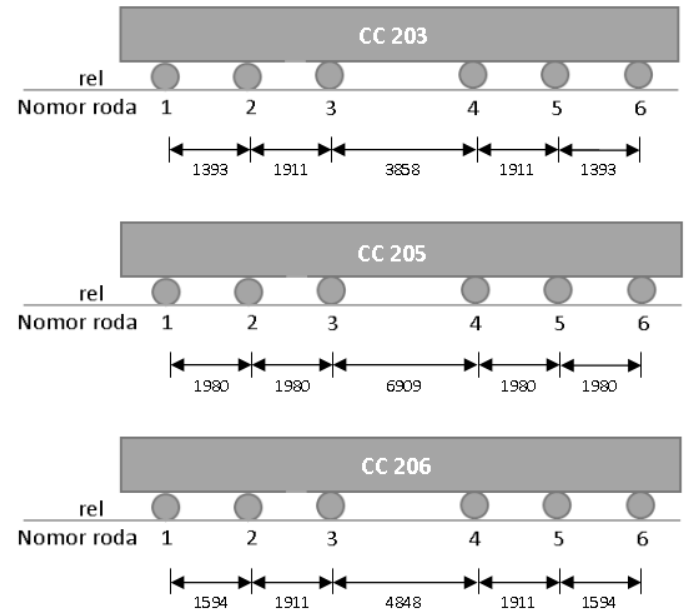

Gambar 4. Jarak antar gandar lokomotif CC 203, CC 205, dan CC 206

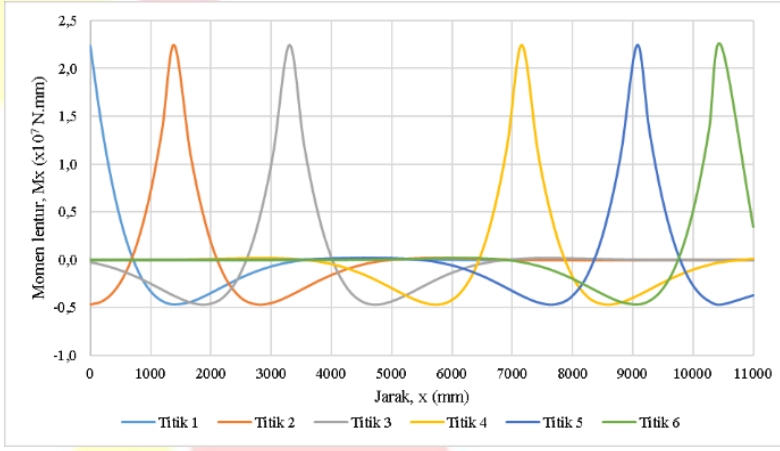

Gambar 5. Tegangan rel akibat beban roda dinamis lokomotif CC 203

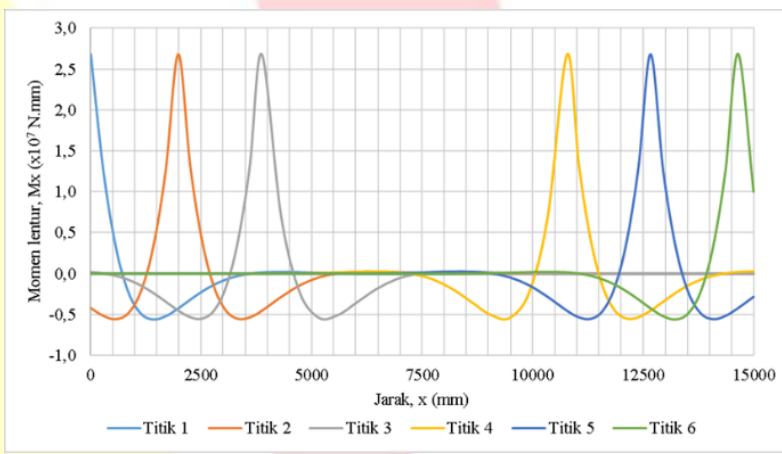

Gambar 6. Tegangan rel akibat beban roda dinamis lokomotif CC 205 


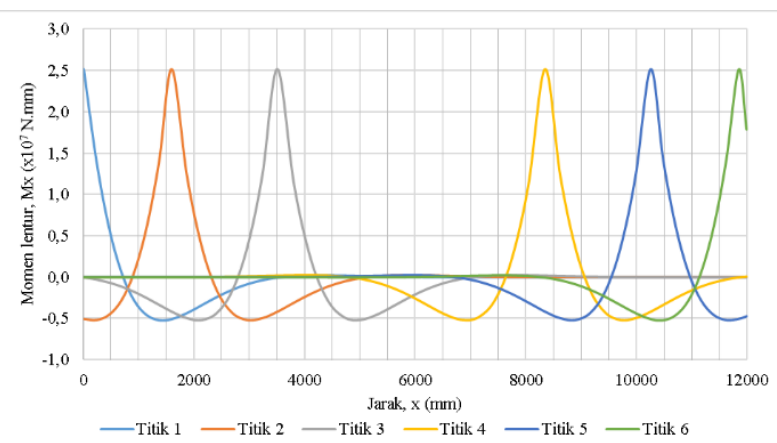

Gambar 7. Tegangan rel akibat beban roda dinamis lokomotif CC 206
Kondisi pembebanan jalan rel aktual menyebabkan rel mengalami kombinasi beban sehingga nilai momen positif dan momen negatif pada setiap titik seharusnya dijumlahkan. Oleh karena itu, untuk perhitungan tegangan rel pada perhitungan angka keamanan (SF) akan menjumlahkan momen lentur positif dan negatif pada rel. Hasil penjumlahan momen tersebut ditampilkan dalam Tabel 5. Data hasil penjumlahan momen rel pada setiap roda lokomotif menunjukkan nilai positif dengan nilai terkritis untuk CC 203, CC 205, dan CC 206 adalah sebesar $1,860 \times 10^{7}$ N.mm; $2,279 \times 10^{7}$ N.mm dan $2,105 \times 10^{7}$ N.mm.

Tabel 5. Hasil analisis tegangan lentur rel dan faktor keamanan (SF) akibat beban lokomotif CC 203

\begin{tabular}{|c|c|c|c|c|c|c|}
\hline $\begin{array}{c}\text { Nomor } \\
\text { roda }\end{array}$ & $\begin{array}{c}\text { Jarak } \\
(\mathbf{m m})\end{array}$ & $\begin{array}{c}\text { Jarak terhadap } \\
\text { acuan }(\mathbf{m m})\end{array}$ & $\begin{array}{c}\text { Momen lentur, Mx } \\
(\mathbf{t . m})\end{array}$ & $\begin{array}{c}\text { Tegangan lentur, } \sigma_{\mathrm{x}} \\
\left(\mathrm{N} / \mathrm{mm}^{2}\right)\end{array}$ & $\begin{array}{c}\text { Tegangan ijin, } \sigma a l l \\
\left(\mathrm{~N} / \mathrm{mm}^{2}\right)\end{array}$ & SF \\
\hline 1 & 0 & 0 & 1,751 & 55,966 & 650,48 & 11,62 \\
\hline 2 & 1393 & 1393 & 1,404 & 44,886 & 650,48 & 14,49 \\
\hline 3 & 3304 & 3304 & 1,860 & 59,447 & 650,48 & 10,94 \\
\hline 4 & 7162 & 7162 & 1,860 & 59,447 & 650,48 & 10,94 \\
\hline 5 & 9073 & 9073 & 1,404 & 44,886 & 650,48 & 14,49 \\
\hline 6 & 10466 & 10466 & 1,751 & 55,966 & 650,48 & 11,62 \\
\hline
\end{tabular}

Tabel 6. Hasil analisis tegangan lentur rel dan faktor keamanan (SF) akibat beban lokomotif CC 205

\begin{tabular}{|c|c|c|c|c|c|c|}
\hline $\begin{array}{c}\text { Nomor } \\
\text { roda }\end{array}$ & $\begin{array}{c}\text { Jarak } \\
(\mathbf{m m})\end{array}$ & $\begin{array}{c}\text { Jarak terhadap } \\
\text { acuan (mm) }\end{array}$ & $\begin{array}{c}\text { Momen lentur, Mx } \\
(\mathbf{t} . \mathbf{m})\end{array}$ & $\begin{array}{c}\text { Tegangan lentur, } \sigma_{\mathrm{x}} \\
\left(\mathrm{N} / \mathrm{mm}^{2}\right)\end{array}$ & $\begin{array}{c}\text { Tegangan ijin, } \sigma a l l \\
\left(\mathrm{~N} / \mathrm{mm}^{2}\right)\end{array}$ & $\mathbf{S F}$ \\
\hline 1 & 0 & 0 & 2,279 & 72,842 & 650,480 & 8,93 \\
\hline 2 & 1980 & 1980 & 1,806 & 57,710 & 650,480 & 11,27 \\
\hline 3 & 3870 & 3870 & 2,245 & 71,736 & 650,480 & 9,07 \\
\hline 4 & 10779 & 10779 & 2,245 & 71,736 & 650,480 & 9,07 \\
\hline 5 & 12669 & 12669 & 1,806 & 57,710 & 650,480 & 11,27 \\
\hline 6 & 14649 & 14649 & 2,279 & 72,842 & 650,480 & 8,93 \\
\hline
\end{tabular}

Tabel 7. Hasil analisis tegangan lentur rel dan faktor keamanan (SF) akibat beban lokomotif CC 206

\begin{tabular}{|c|c|c|c|c|c|c|}
\hline $\begin{array}{c}\text { Nomor } \\
\text { roda }\end{array}$ & $\begin{array}{c}\text { Jarak } \\
(\mathbf{m m})\end{array}$ & $\begin{array}{c}\text { Jarak terhadap } \\
\text { acuan }(\mathbf{m m})\end{array}$ & $\begin{array}{c}\text { Momen lentur, Mx } \\
(\mathbf{t . m})\end{array}$ & $\begin{array}{c}\text { Tegangan lentur, } \sigma_{\mathrm{x}} \\
\left(\mathrm{N} / \mathrm{mm}^{2}\right)\end{array}$ & $\begin{array}{c}\text { Tegangan ijin, } \sigma a l l \\
\left(\mathrm{~N} / \mathrm{mm}^{2}\right)\end{array}$ & $\mathbf{S F}$ \\
\hline 1 & 0 & 0 & 2,001 & 63,959 & 650,480 & 10,17 \\
\hline 2 & 1593,85 & 1593,85 & 1,586 & 50,691 & 650,480 & 12,83 \\
\hline 3 & 3505,2 & 3505,2 & 2,105 & 67,260 & 650,480 & 9,67 \\
\hline 4 & 8352,93 & 8352,93 & 2,105 & 67,260 & 650,480 & 9,67 \\
\hline 5 & 10264,28 & 10264,28 & 1,586 & 50,691 & 650,480 & 12,83 \\
\hline 6 & 11858,13 & 11858,13 & 2,001 & 63,959 & 650,480 & 10,17 \\
\hline
\end{tabular}


Angka keamanan (SF) terkritis akibat beban lokomotif CC 203, CC 205, dan CC 206 adalah 10,94; 8,93; dan 9,67. Seluruh nilai angka keamanan (SF) rel akibat beban lokomotif terkritis pada Tabel 5, Tabel 6, dan Tabel 7 menunjukkan bahwa seluruh nilai $\mathrm{SF}>1$, sehingga rel UIC54 aman dalam menahan beban roda lokomotif yang melintasinya. Nilai SF menunjukkan tingkat kepercayadirian seorang perencana struktur dalam menjamin kekuatan stuktur untuk menahan beban. Sampai saat penelitian ini ditulis, penulis belum menemukan nilai SF yang disarankan untuk menjamin keamanan struktur rel yang dihitung dengan metode BoEF. Untuk perhitungan BoEF yang lebih teliti, penelitian ini dapat dikembangkan dengan melakukan pengujian tegangan leleh baja rel untuk analisis tegangan lentur bawah rel; serta mengevaluasi tegangan pada tepi bawah dan tepi atas kepala rel yang juga merupakan lokasi terjadinya tegangan maksimum akibat beban roda.

\section{KESIMPULAN}

Berdasarkan hasil analisis yang telah dilaksanakan, dapat disimpulkan beberpa hal sebagai berikut:

a. Beban roda dinamis lokomotif kereta untuk CC 203, CC 205, dan CC 206 secara berturutturut adalah 98710,94 N, 118222,22 N, dan $110709,38 \mathrm{~N}$.

b. Tegangan lentur maksimum rel terjadi pada rel yang terletak tepat di bawah roda. Momen lentur terkritis hasil kombinasi momen lentur akibat roda yang saling berdekatan pada CC 203, CC 205, dan CC 206 adalah 1,860 x 107 N.mm; 2,279 x 107 N.mm dan 2,105 x 107 N.mm.

c. Tegangan lentur ijin rel UIC 54 menggunakan persamaan AREA adalah sebesar 650,48 MPa pada kondisi baja rel dalam kondisi tegangan ultimit atau tegangan tarik.

d. Angka keamanan (SF) rel UIC 54 bervariasi tergantung jarak antar roda dan beban lokomotif yang melintasinya. Angka keamanan terkritis akibat beban lokomotif CC 203, CC 205, dan CC 206, yaitu sebesar 10,94; 8,93 ; dan 9,67. Seluruh nilai $\mathrm{SF}>1$ sehingga rel dinyatakan aman dalam menerima beban roda.

\section{DAFTAR PUSTAKA}

Doyle, N. (1980). Railway Track Design A Review Of Current Practice. Canberra: Australian Goverment Publishing Service.
Dwiatmoko, H. (2016). Pengujian Sarana Perkeretaapian. Jakarta: Prenadamedia Group.

http://www.jfe-steel.co.jp/en/.

Republik Indonesia. (2002). SNI 03-1729-2002 tentang Tata Cara Perencanaan Struktur Baja untuk Bangunan Gedung. Jakarta: Departemen Pekerjaan Umum.

Republik Indonesia. (2012). Peraturan Menteri Perhubungan Nomor 60 tahun 2012 tentang Spesifikasi Teknis Jalan Rel. Jakarta: Kementerian Perhubungan. 